\title{
The Battle for World Opinion
}

\section{F. William Smullen*}

\begin{abstract}
America's standing in the world is at stake. Nations and peoples around the world feel a deep and abiding anger and resentment towards the United States. This affects America's ability to influence the judgment and actions of those who resist her sense of being able to do whatever she wants to do as a nation. This article suggests changes in American policy that are necessary to bring about the results America seeks.
\end{abstract}

Keywords: Public diplomacy, policy, opinion, international, America

\section{A shift in attitudes}

1 s a member of a seven-person committee mandated by the U.S. Congress in March of 2004 to study the attitudes and opinions of peoples of other countries toward the United States, I set out to learn if we were winning or losing the battle for world opinion. On behalf of and in cooperation with the U.S. Department of State, the committee traveled in the summer of 2004 to countries in the Middle East and Europe to survey attitudes toward the U.S. of people of all ages and in all sectors of society in those parts of the world. What we discovered was that America's image and reputation could hardly be worse. There was then and continues to be a deep and abiding anger toward U.S. policies and actions. ${ }^{1}$

The findings contrasted markedly from the expressions of caring and support I had witnessed in the fall of 2001. Then, as the Chief of Staff to Secretary of State Colin L. Powell, I watched a parade of foreign leaders march through Washington D.C. offering their respect and condolences in the wake of the September 11 terrorist attacks on America and in effect on the world.

There was recognition that together we were in a new fight, one against terrorism. America had been a prime target of terrorists, and the outreach by friends and allies expressing unity and support was heartwarming. There seemed to be a consensus by freedom-loving nations that the world was being confronted with challenges never faced before and solutions never tried before.

The October 2001 invasion of Afghanistan in retaliation for the events of 9/11 had been seen by much of the world as reasonable and understandable. The next May, President Bush adopted a new national security paradigm - a preemptive approach to doing business. Growing signs of unilateralism by the U.S., in particular the 2003 invasion of Iraq, illustrated that we don't always get it right as was the case of our predicting we'd find weapons of mass distruction (WMD) there. This caused a shift in attitudes both at home and especially abroad toward our aggressive approach. Indeed the world grew either angry or wary

\footnotetext{
* Retired U.S. Army Colonel F. William Smullen, III is the Director of National Security Studies at the Maxwell School of Citizenship and Public Affairs and a Professor of Public Relations at the S.I. Newhouse School of Public Communications at Syracuse University. He served as a professional soldier for 30 years. Prior to his dual appointment at Syracuse he was the Chief of Staff to Secretary of State Colin. L. Powell and of the U.S. Department of State.

1 United States. Advisory Committee on Cultural Diplomacy. Cultural Diplomacy: The Linchpin of Public Diplomacy. Washington D.C.: 2005. < http://www. maxwell.syr.edu/inside/StateCommitteeReport.pdf >.
}

of the United States for doing what it pleased as it invaded Iraq without world agreement with or support of that action.

\section{How we see ourselves}

We Americans sometimes see the United States as the fixed center of the universe with other nations and events revolving around us. On the one hand it's one of our endearing qualities. We as a nation and a people have grown comfortable that as a Republic we were destined at birth to hold a unique place in history.

Indeed, destiny has been on our side for over two centuries. We see ourselves as a special brand of people who reside in a special kind of democratic society. President Ronald Reagan called it a "shining city on a hill".

And all of that is fine with one exception. Regrettably, others around the world don't view us the same way. As a result of our invading Afghanistan and then Iraq, among other things, they tend to see us as a monolithic empire choosing to do whatever we want, wherever we want and whenever we want.

\section{America's brand}

That has resulted in the decline of what some see as America's brand, a marketing term associated not with what you say about a company, product or service but what you do, how you do it and why, as you conduct your business. America's brand, as it has been described, is its image and reputation - good or bad that exists in the minds of billions of people around the world. So what America does, how we do it and why directly shapes the world's opinion of America's brand. Based on numerous surveys and measurements taken over the past several years, the reputation of brand America has been in steep decline. ${ }^{2}$

This is particularly true in both the Muslim and European worlds, but it's true too in countries around the globe of particular importance to us as allies and trading partners. According to the 2006 Pew Global Attitudes Project, favorability ratings towards the United States in countries like Great Britain,

2 Keith Reinhard's comments on the American brand. The 9-11 Commission Recommendations on Public Diplomacy: Defending Ideals and Defining the Message, hearing before the House Government Reform Subcommittee on National Security, Emerging Threats and International Relations, August 23, 2004, p. 6 
France, Germany, Spain, Japan, Turkey and Indonesia fell in each of the years from 2000 to 2006.

A broader, more revealing World Service Survey by the BBC of 26 thousand respondents in 25 countries was released on January 23,2007 . It found that a majority of those polled held negative views of U.S. policies on a wide range of issues.

One of the most startling indicators of dissatisfaction with America was a South Korean newspaper poll taken of younger people there after the Iraq invasion. Of those surveyed, 65.9\% said, if a war were to break out between the U.S. and North Korea, they would side with their neighbors to the north. So much for a half century of force protection.

Even in Africa, according to a recent Pew Global Attitudes Project, most nations in Africa have more positive views of China than of the U.S. China's "charm offensive" contrasts with our lack of charm in people's minds.

\section{Why it matters}

A wave of anti-Americanism has broken out. Whether that negative reaction is directed at policy or people, all available research indicates four definable root causes:

1. Widespread disagreement with current U.S. foreign policy;

2. A perception that U.S.-led global expansion has been exploitive and unilateral in nature;

3. A feeling that U.S. pop culture has become all-pervasive and disturbing; and

4. Seeing Americans as arrogant, insensitive, ignorant and loud. ${ }^{3}$

Many Americans simply don't care how foreigners have come to think of the United States or themselves. They should for reasons of pride alone. But if not that, they should come to understand the impact on their economy and their financial portfolios by the boycott of U.S. products taking place by people around the world, particularly in Europe and Asia, simply out of protest. Most importantly, they should care because the U.S. needs willing partners to help fight the global war against terrorist organizations, 30 of which have come into existence since $9 / 11$.

Terrorism is growing at an extraordinarily rapid rate. Twentysix nations have been attacked since that fateful day for America in 2001. Terrorist organizations reside in some 60 sanctuaries around the globe. It's a growing problem; it's also a global problem. The U.S. needs the cooperation of governments who can help provide a global solution.

\section{Resolving conflict}

When in conflict - and freedom-loving nations of the world are in conflict with terrorism - it is imperative to engage in conflict resolution. It is more essential now than at any time since the end of World War II. In a bipolar world for the better part of 45

3 Ibid. years following that war, the one supposedly to end all wars, the potential for conflict was solved for the most part by two nations - the U.S. and the U.S.S.R. These two superpowers were surrounded by the many countries of the world that aligned themselves with either for political, military or economic reasons.

With only one superpower today and no longer the same need for those earlier satellite relationships, most countries are on their own to resolve problems and differences for themselves. Conflict resolution takes on greater importance, therefore, and needs to be better understood. In turn, partnerships need to be more formal and effective to fight common enemies.

With respect to countering terrorism, it is imperative to move strategic thinking and corrective action to a higher level. It will take the implementation of an insightful and aggressive plan to combat a war we're losing numerically. The free world is being out-recruited by Osama Bin Laden and extremists like him. They ubiquitously use the internet to offer young people a certain form of respect, hope and encouragement to join them in the violence and death they perpetuate.

Nations of the world which reside on the side of what's just must offer alternatives and engage in this war of ideas. This can start by first listening to the disgruntled and providing opportunities to young people beyond what they already have or have to look forward to.

America can lead that movement and at the same time improve its image. But it must get busy and develop a plan of action that starts with an understanding and sensitivity to other cultures and peoples. It must be based on knowing more about and reaching out to various demographic age groups and audiences from the elite to the youth of a country or region. It must have a resonating message that is projected with sensitivity. It must advocate values that have a common good. Values like family, community, faith, and the desire for education come to mind. If we don't, pity help us as we confront a prevalent and escalating enemy known as terrorism and its threat to people who want to live securely.

For America, it means taking a lead role and projecting the kind of global leadership that garners respect. That equates among other things to success with the insurgency in Iraq, strategic rapprochement with Iran and movement toward a resolution of differences between the Israelis and the Palestinians.

\section{Leadership matters}

Most importantly, this is a time for change to many things America does and the way she does them at the national level. That can and must start with a change in leadership style in the White House beginning in January 2009. Notwithstanding the fact that anti-Americanism will continue to exist, it can coexist with international demands for America to be a leader in world affairs. What we could use is a "Persuader-in-Chief" in the White House, someone who can inspire other nations to help face up to the challenges of the day. 
Any U.S. President should be elected based on several factors - proven experience, sound judgment, demonstrated leadership and promising vision. Authenticity ought to be the yardstick by which the electorate of this country selects its head of state. America needs a President who is ready and willing to make decisions that are courageous. Decisions that are based not on politics or party but on learning from and facing up to successes and mistakes - theirs and those of others before them that have held the highest office.

Our next President can draw from the lessons of courageous Presidents past, as historian Michael Beschloss describes in his book "Presidential Courage". Presidents like Abraham Lincoln, who in 1864 was warned by friends and advisors that his "Emancipation Proclamation" would cost him the election that year. He said he would not renounce it because he'd "rather be right than President". ${ }^{4}$

Presidents like Franklin Deleanor Roosevelt, who made a similar decision when he asked a nation to mount a defense against and come to the aid of allies fighting Adolf Hitler. He could have chosen not to invest American blood and treasure, but he defended the greater good of mankind. ${ }^{5}$

Presidents like John F. Kennedy who asked the nation and the Congress for a major civil rights bill without which our social fabric as a people could have been ripped apart. As a matter of principle, he was willing to go down in reelection defeat if it was not passed. Regrettably, he didn't live to see the good his courage brought about. ${ }^{6}$

They were examples of Presidential courage without which we wouldn't have an America or a world as we know it today. Next November we Americans need to elect someone to the highest office who can and will have the courage and the vision to move the United States beyond its present position to a better place. America needs to stand out as a beacon of what's right in and for the world. That is important for a nation which is in a period of decline, a condition that must be stopped and reversed in America's case.

\section{Critical issues}

There are a number of issues on which the Presidential candidates can and should be judged. Two issues in particular, foreign policy and national security, stand out because they have such a bearing on how America positions itself on the world stage.

The next American President needs to revive diplomacy and subordinate the use of military force. That person should be someone who has traveled extensively abroad, knows world leaders and will be a respected head of state by virtue of experience and performance.

With respect to their views on foreign policy, it's important to know how the candidates would resolve the situation in Iraq, advance reconstruction, and help stand up a self-sufficient gov-

\footnotetext{
4 Michael Beschloss. Presidential Courage: Brave Leaders and How They Changed America 1789-1989. New York: 2007, p 101.

5 Ibid, pp. 188-192.

6 Ibid. pp. $270-276$
}

ernment and military force there. Additionally, as the Commander-in-Chief, what their thinking would be on whether the unilateral use of U.S. military force is acceptable is a major consideration.

How they would work to put the Middle East peace process back on the map is central to the future of that region of the world. How they would deal with a nuclear ambitious Iran is relevant to the region as well.

National security is more than defense of the homeland. The next U.S. President needs to have a global vision and be committed to the war on terrorism as it affects the world. How Presidential candidates if elected would forge stronger relationships with countries where terrorist organizations like al Qaeda can be routed from their sanctuaries is a significant factor. In that regard, the next U.S. President must share useful intelligence with friends and allies internationally to find and put down known terrorists.

These issues begin to form a framework wherein the instinct, the judgment and the intellectual adroitness of candidates can be gauged. Making that right choice can inspire the people of this nation and the leaders and peoples of other nations to pursue just causes, have worthy goals and engage in a strategic vision to accomplish things good for humankind. America can lead this effort by choosing someone willing to export hope and optimism based on common values that people everywhere can get behind and support.

\section{Alliances and agreements}

One way to begin this movement is for the United States to reacquaint and realign itself with alliances and multilateral organizations from which it has become isolated or grown estranged. A starting point would be a renewed commitment to the United Nations with whom the United States has been at odds over the past several years on such issues as international law, energy and climate.

The United States needs to renew its commitment to age-old alliances like NATO, ASEAN and the EU. They can help raise the level of dialogue, resolve differences and form agreements on such issues as global health, energy, security, nonproliferation and climate.

America has distanced itself from agreements much of the world stands behind. They run the gamut: the International Criminal court; the Kyoto Protocol on climate change; the Mine Ban Treaty; the Anti-Ballistic Missile Treaty; and the Convention on the Rights of the Child. When you continually reject initiatives that other nations view as credible, it simply doesn't help your standing in the world. Nations have reacted accordingly with a range of emotions toward the United States: opposition; anger; disillusionment; wariness; outright distrust. Eventually, they tend to ignore or see the bully nation as irrelevant.

As the world's only superpower, America must retrieve its moral authority so its word will be heard and heeded. To get there as a nation America must look like a leader, act like a leader, be a leader. A rebranding of America will help. 


\section{Seeking change}

There are actually three things, in a broader sense and in particular, that we must seek to change to regain that position of respected leadership: change to our public policy; change to our public diplomacy; and change to our public involvement. The coming together of these three pieces that must fit tightly is a form of triangulation.

With respect to public policy, we need to discard the "justified or not, fact based or not, 'our response' is what matters" approach we adopted in response to 9/11. We must return to "analysis first, followed only then by an appropriate and measured response". The United States must dump the threats, declarations and denunciations and replace them with partnerships, collaborations and cooperation, something we've started to do but must do more of. ${ }^{7}$

With regard to public diplomacy, we must get beyond threatening our enemies or adversaries with military action or sanctions and get back to the bedrock principle of diplomatic dialogue. Much like the elements of conflict resolution, success in diplomacy rests on many things: the history of differences; the personalities and skills of the negotiators; the language used along the way; the strategy adopted; an unstated willingness to compromise; the ability to adjust to and adopt some middle ground; timing of the negotiations; levels of dialogue; and factoring in a mistake quotient.

And when it comes to public involvement, Americans need to realize that the U.S.'s standing in the world is their responsibility too. They have a stake in the outcome and can contribute to a helpful course in little ways individually but mighty ways collectively. Actually, when a person realizes they can make a recognizable difference it empowers them to do more. In each of these three efforts, it would be wise to heed the views of our third President, Thomas Jefferson. In 1776, when drafting our Declaration of Independence he called for "a decent respect to the opinions of mankind". That philosophy still holds strength to this day.

When it comes to all three sides of the triangle - public policy, public diplomacy and public involvement - some relevant thoughts are in order. The first is that the age of military ascendancy is coming to an end. The radicals and militants faced by Israel in Lebanon in 2006, by the Americans in Afghanistan since 2001 and in Iraq since 2003 should signify to the observant that unconventional tactics can prevent conventional armies from achieving desired results.

Had our leaders paid more attention to history before our Army went into Iraq they would have better anticipated the difficulty of the task. Even Winston Churchill, while Britain's Colonial Secretary there in 1922, couldn't figure out Mesopotamia, as Iraq was then called. He wrote his Prime Minister, David Lloyd George, and asked, "Why are we compelled to go on pouring

\footnotetext{
7 Ron Suskind. The One Percent Doctrine: Deep Inside America's Pursuit of Its En-
} emies Since 9/11. New York: 2006, pp. 62,170. armies and treasure into these thankless deserts?" If only we had realized five years ago how prescient this was. ${ }^{8}$

Today Iraq is immersed in another grave occurrence - a civil war between Sunnis and Shiites that if not contained and resolved could spread to neighboring countries. That was not anticipated in 2003 nor was there a plan for post-conflict stability and reconstruction. As a result, we are experiencing a drain on our monetary and manpower resources that is both taxing and embarrassing. Our patience as a people is being tested. There is a tarnish to our value system. Meanwhile, we're losing the battle for world opinion to an almost humiliating degree.

Historically, empires in decline have tended to overestimate their own strengths and underestimate the capabilities of their adversaries. U.S. policymakers need to understand and accept the fact that the use of force is not the strategic instrument of choice anymore. We must see the fight ahead as a battle of ideas not a battle of might.

That battle of ideas will require fresh thinking, patience, restraint, sound judgment and diplomatic agility - qualities not found in abundance in recent U.S. policy making. This is not about becoming isolationists; but from a policy standpoint, it must be about being more concerned with defense than offense. What we are doing well for the most part - guarding our borders - we need to invest in more heavily and aggressively so that the ability of militant extremists to penetrate North America remains difficult for them.

As for public diplomacy, we need to be smarter and move faster. We need to open up avenues of dialogue and understand better the art of compromise. We can't always have it our way, but we can find common ground and the best way forward.

Regarding public involvement, it's not just time for the U.S. government but for every American citizen who cares to become more active and engaged in ways to influence public opinion in capitals around the world in positive ways. Something as meaningful as hosting an international visitor or volunteering abroad would make a big difference.

This is about reforming our approach to doing business with the nations and the peoples of the world. It's about influencing their behavior toward us and affecting their perceptions of us in the long term by setting a solid example that Americans have strong values that matter. It is also about creating and fostering enduring relationships with other peoples, and convincing them that we want to help create a foundation of trust with them.

There are some historically admired qualities about America. Positive qualities like opportunity, freedom, innovation, benevolence, volunteerism, creativity, technology, education, diversity, competitive spirit, and striving to be the best. We ought not to shrink from demonstrating these qualities for they serve as models for others to emulate.

But there are other qualities we should strive to be known for as well. Qualities like honesty, integrity, being a model of citi-

8 Joe Klein. “Even Churchill Couldn't Figure Out Iraq." TIME, August 7, 2006, Vol. 168, No. 6. Klein quotes Churchill's conversation to Lloyd George during the First World War. 
zenship and ethics, having an understanding of other cultures and religions, listening to and learning from others and being a leader that others can count on.

At the same time, we need to show we don't intend to impose our will anywhere we choose. And we can't afford to feel or act as if we can impose our will virtually alone. For if we do either, we can count on little or no support or cooperation from those around the world who have grown to either hate or fear us.

\section{The use of power}

What we need to do is pass these three public tests - those of policy, diplomacy and involvement. We must invest our time, treasure and talent in strengthening the bonds of international cooperation. It starts with what Richard L. Armitage, the former U.S. Deputy Secretary of State, and Joseph S. Nye, Jr., the former Dean of the Kennedy School at Harvard, call "Smart Power", in their bipartisan commission report published in late 2007.

Their thesis is that "the United States must become a smarter power by once again investing in the global good - providing things people and governments in all quarters of the world want but cannot attain in the absence of American leadership".
This plays off of what Nye in his book Soft Power describes as the ability to get what you want through an attraction of who you are rather than by coercion or payment. Nye advocates getting others to admire your ideals and do what you want or profess because they believe in it as opposed to you imposing those ideals on them because you simply say those ideals are right. ${ }^{9}$

As a nation, we need to strive for that soft power attractiveness to our culture, our political ideals and our policies. These are times to be clear eyed and sure footed as a nation with respect to our foreign policy as it is applied to global issues at play on the world stage. ${ }^{10}$

For the world, the challenges and consequences of the moment are enormous. For the United States, this moment offers the opportunity to bind the wounds to reputation with decisions that can heal image and influence. Doing so can responsibly contribute to making the world a better place and at the same time can earn respect as a solid citizen-nation of the world. It is a watershed moment that cannot be squandered.

9 Richard L Armitage and Joseph S. Nye Jr "CSIS Commission on Smart Power: A Smarter, More Secure America." Washington D.C.: 2007, p.1.

10 Joseph S. Nye, Jr. Soft Power: The Means to Success in World Politics. New York: 2004.

\title{
The UN-US pas de deux
}

\section{Ramesh Thakur ${ }^{1}$}

\begin{abstract}
This chapter examines the relationship between the United States as the universal power and the United Nations as the universal organisation in terms of four critical areas: the use of force, peace operations, nuclear weapons and climate change. Neither the US nor the UN can dispense with the other, yet their mutual dependence is asymmetrical. The material capacity to deploy and use force globally is concentrated in the United States, while the authority to do so is legally vested in the UN Security Council. The latter is the proper locus of authorising and legitimising the creation, deployment and use of military force under international auspices. Multilateralism remains important to US foreign policy, and the US is the pivot of multilateral action for the maintenance of international peace and security. Because the US will remain the main financial underwriter of UN peacekeeping costs, it will continue to exercise unmatched influence on UN peace operations. The hard core of negotiations on issues of nuclear stockpiles will be conducted among the nine nuclear powers directly. But they can draw on world moral authority via the UN. On climate change, Washington and the UN will have to work cooperatively to convert the formula of common but differentiated responsibility into action. During the primary campaign, the candidates Clinton, McCain and Obama showed interesting differences on these issues as an anticipatory guide to how their administrations might frame policies.
\end{abstract}

Keywords: UN, nuclear weapons, use of force, peace operations, climate change; VN, Nuklearwaffen, Gewaltanwendung, Friedensmissionen, Klimawandel

A merica matters, what America does and does not do matters and so the choice of who leads America matters to all other nations. It is impossible for the world to move forward if America decides to stand still and refuses to budge, as on climate change. It is impossible for the world to avoid a tsunami of misfortunes when America takes a misstep, as in Iraq. This is why outsiders followed the progress of the American presidential campaigns within and then between the

1 Dr., Distinguished Fellow at The Centre for International Governance Innovation in Waterloo, Ontario Canada. parties with a mixture of eagerness, apprehension and fretfulness.

The incoming administration will confront a congested menu of domestic and foreign policy items demanding immediate attention. He or she, required to separate the urgent from the merely important, will be fortunate if the Bush administration has left behind just unfinished business instead of a full-blown crisis or two. "Moreover, in dealing with that morass, the US will need help from a world where its reputation is scraping bottom, from an enfeebled United Nations and from allies whose 